\title{
Symbols and Meanings of Kanji with Bushu Onnahen as Representation of Women
}

Nani Sunarni ${ }^{\mathbf{1}}$

Universitas Padjadjaran, Sumedang, Indonesia

\begin{tabular}{|c|c|}
\hline Article History & Abstract \\
\hline $\begin{array}{l}\text { Submitted date: } \\
\text { 2021-09-30 } \\
\text { Accepted date: } \\
\text { 2021-11-25 } \\
\text { Published date: } \\
\text { 2021-11-30 } \\
\text { Keywords: } \\
\text { gender; japanese; Kanji; } \\
\text { onnahen; japanese } \\
\text { woman }\end{array}$ & $\begin{array}{l}\text { Kanji are characters used in Japanese which are the result of Chinese thought adopted } \\
\text { by Japanese society. The main elements in Kanji (bushu) can be gender markers, } \\
\text { water, trees, and others. One of these elements is a female gender symbol called } \\
\text { onnahen. The data used in this study, in the form of Kanji with bushu onnahen. The } \\
\text { data were analyzed based on the theory of semiotics and hypersemiotics which view } \\
\text { Kanji as a cultural phenomenon. The results of the analysis identified that the female } \\
\text { symbol in the Kanji with bushu onnahen represents that Japanese woman have a } \\
\text { respectable character when they become a wife and mother, are authoritative, } \\
\text { trustworthy, helpful, but have no character, are false, selfish, and jealous. } \\
\text { Theoretically, this research is useful to add references in the study of gender and Kanji. }\end{array}$ \\
\hline & Abstrak \\
\hline $\begin{array}{l}\text { Kata Kunci: } \\
\text { gender; Jepang; Kanji; } \\
\text { onnahen, perempuan } \\
\text { Jepang }\end{array}$ & $\begin{array}{l}\text { Simbol dan Makna Kanji Ber-bushu onnahen sebagai Representasi Perempuan } \\
\text { Kanji merupakan aksara yang digunakan dalam bahasa Jepang sebagai hasil pemikiran } \\
\text { orang Cina yang diadopsi masyarakat Jepang. Unsur utama dalam Kanji (bushu) dapat } \\
\text { berupa penanda gender, air, pohon, dan lain-lain. Salah satu di antara unsur tersebut } \\
\text { adalah simbol gender perempuan yang disebut onnahen. Data yang digunakan dalam } \\
\text { penelitian ini, berupa Kanji yang ber-bushu onnahen. Data dianalisis berlandaskan } \\
\text { pada teori semiotika dan hipersemiotika yang memandang Kanji sebagai fenomena } \\
\text { budaya. Hasil analisis teridentifikasi bahwa simbol perempuan dalam Kanji ber-bushu } \\
\text { onnahen merepresentasikan bahwa perempuan Jepang memiliki karakter terhormat } \\
\text { bila sudah menjadi seorang istri dan menjadi ibu, berwibawa, dapat dipercaya, } \\
\text { penolong, namun sebaliknya berkarakter tidak memiliki pendirian, palsu, egois, dan } \\
\text { pencemburu. Secara teoretis penelitian ini bermanfaat untuk menambah referensi } \\
\text { dalam kajian gender dan Kanji. }\end{array}$ \\
\hline
\end{tabular}

\section{Pendahuluan}

Jepang merupakan salah satu negara maju di Asia Timur. Kemajuan Jepang tidaklah lepas dari berbagai faktor yang dilakukan masyarakat Jepang yang menganut konsep harmoni atau wa dan konsep kolektif atau shuudan shugi dalam seluruh kehidupannya (Yoshikazu, 1991). Implementasi konsep-konsep dalam keseluruhan kehidupannya tersebut mampu menjadikan Jepang sebagai negara maju. Tidak hanya faktor di atas yang membuat kemajuan Jepang tersebut, namun salah satu faktor pendukung kemajuan Jepang pun tidak terlepas dari kontribusi perempuan Jepang

\footnotetext{
Corresponding author:

1nani.sunarni@unpad.ac.id 
dengan berbagai karakteristik dan kebiasaan yang dilakukannya dalam menjalankan perannya sebagai makhluk pendukung keberhasilan bangsanya. Karakteristik dari perempuan Jepang tersebut salah satunya tercermin dalam aksara Kanji.

Kanji pada awalnya adalah aksara Han yang ditemukan di Cina sekitar tahun 1600-1066 sebelum Masehi. Kemudian masuk ke Jepang sekitar abad ke-5 (Kess \& Miyamoto, 1999, p. 14). Setelah masuk ke Jepang, baik bentuk maupun bunyi, Kanji mengalami penyesuaian dengan mengikuti sistem pola pikir dan cara baca bangsa Jepang sehingga dihasilkan Kanji buatan Jepang. Selain itu, dari segi bunyi atau cara baca pun dihasilkan dua cara baca yaitu cara baca ala Cina yang disebut on yomi dan cara baca ala Jepang yang disebut kun yomi. Bahkan selain penyesuaian di atas terdapat pula penyederhanaan Kanji yang akhirnya terwujud huruf Hiragana dan Katakana. Kanji yang dipelajari dalam jenjang pendidikan dasar dan menengah sembilan (9) tahun disebut Jooyoo kanji yang berjumlah 2.136 buah.

Dari segi jumlah unsur pembentuknya Kanji terbagi menjadi dua yaitu Kanji tunggal (Kanji yang terbentuk dari satu unsur) dan Kanji gabungan (awase moji) atau complex words yaitu satu buah Kanji yang terbentuk dari beberapa unsur (Endo, 1986, p. 14). Dalam Kanji gabungan terdapat bagian yang paling penting yang disebut bushu. Bushu terdiri atas dua silabel yaitu bu (bagian) dan shu (leher). Jadi, bushu adalah bagian leher dari Kanji.

Dalam kehidupan sehari-hari bagi masyarakat Jepang leher merupakan bagian organ tubuh yang paling penting. Karena bila manusia tidak berleher berarti tubuh bagian atas tidak ada, berarti manusia mati. Manusia mati tidak memiliki makna. Begitu pula leher (bushu) dalam Kanji ibarat leher sebagai organ tubuh manusia. Oleh karena itu, keberadaan leher (bushu) menjadi sangat penting dalam Kanji karena merupakan bagian pembentuk makna (Endo, 1986, p. 21). Salah satu bushu (leher) dalam Kanji sebagai pembentuk makna ditandai oleh simbol perempuan yaitu onna 女 (perempuan) yang muncul di sebelah kiri Kanji yang melekatinya atau disebut onnahen - 女偏 (berleher perempuan). Dalam bahasa Jepang perempuan disebut onna（女） atau josei（女性). Dalam penelitian ini istilah perempuan yang digunakan adalah onna dengan simbol 女 (onna) yang menjadi bushu (onnahen) sebagai bushu yang merepresentasikan perempuan Jepang.

Dalam masyarakat Jepang, perempuan sering dipandang sebagai makhluk lemah atau rendah yang disimbolkan dengan kelingking. Sebaliknya perempuan dipandang pula sebagai makhluk yang kuat. Oleh karena itu, kajian ini penting dilakukan untuk mengidentifikasi Kanji ber-bushu onnahen sebagai simbol yang merepresentasikan perempuan Jepang. Penelitian yang terkait dengan bushu telah dilakukan oleh Khoiriyah dalam tulisannya yang berjudul Mengenal Lebih Dekat Mengenai Bushu Kanji. Hasil dari penelitian ini teridentifikasi bahwa dengan mengenal bushu dapat mempermudah memahami makna Kanji (Khoiriyah, 2014). Berdasarkan penelitian sebelumnya penelitian Kanji berbushu onnahen yang menyatakan representasi perempuan Jepang belum ada yang meneliti. Oleh karena itu penelitian ini menjadi penting untuk dilakukan.

\section{Metode Penelitian}

Data yang digunakan dalam penelitian ini adalah Kanji kaii moji ber-bushu simbol perempuan (onnahen). Kaii moji adalah Kanji gabungan yang tidak menghiraukan bunyi akan tetapi membentuk makna baru berdasarkan kedua makna unsur pembentuk Kanji tersebut. Definisi ini diperkuat pula oleh Yoshida yang menyebutkan bahwa kaii-moji adalah jenis karakter yang terbentuk dari kombinasi karakter hieroglif dengan karakter tanda yang mempertahankan makna asli dengan tidak 
menghiraukan bunyi (Yoshida, 1969, p. ix). Data kajian ini bersumber dari buku Nippongo 7 Kanji karya Endo (Endo, 1986).

Kanji merupakan aksara yang bersifat morfemis. Dalam Kanji gabungan, satu karakter merupakan satu morfem sekaligus satu suku kata. Jadi, satu karakter menyatakan satu makna. Karakter dalam kajian ini menunjukkan suatu tanda. Tanda terbentuk dari beberapa unsur dan salah satunya adalah unsur yang menyimbolkan perempuan.

Semua yang ada dalam kehidupan dipandang sebagai tanda yang memiliki makna. Menurut pandangan semiotik De Saussure, tanda merupakan sesuatu yang terstruktur sebagai pertemuan bentuk atau penanda atau signifiant atau dalam bahasa Inggris disebut signifier dengan penanda atau signifie atau signifier yang dipahami oleh pengguna tanda (Berger, 2010, p. 35). Hubungan antara bentuk dan makna bersifat sosial yang didasari oleh kesepakatan atau konvensi sosial (Hoed, 2011 , p. 3). Oleh karena itu, untuk mengkaji tanda digunakan pendekatan ilmu tanda yang disebut semiotik. Bahkan, dalam kajian ini untuk mengidentifikasi model informasi makna dan ekspresinya yang berkaitan dengan fungsi (functional semantics) digunakan teori hipersemiotika. Hipersemiotika dapat dipahami sebagai semiotika yang melampaui batas, terlebih lagi dalam dikotomi tanda dan realitas. Piliang mendefinisikan hipersemiotika sebagai "ilmu tentang produksi dan penggunaan tanda yang melampaui batas serta fungsi konvensionalnya sebagai media komunikasi". Dalam kajian ini, Kanji dianggap sebagai produk budaya yang mencerminkan penandanya (Piliang, 2003, p. 54).

Penelitian ini dilakukan melalui proses koleksi data, analisis data, dan penarikan simpulan. Dalam proses koleksi data pertama kali dilakukan melalui penyimakan pada sumber data. Dari proses ini terkumpul 29 Kanji yang ber-bushu dengan simbol perempuan. Tahap kedua, dilakukan reduksi data berdasarkan letak bushu (leher). Dari proses ini teridentifikasi 25 Kanji ber-bushu simbol perempuan yang terletak di kiri (hen). Empat buah Kanji tidak dijadikan data karena tidak ber-bushu hen. Tahap selanjutnya dilakukan reduksi dan hanya Kanji yang menyatakan peran perempuan sebagai fungsi domestik keluarga saja yang dijadikan data. Dari proses ini didapat tujuh buah Kanji.

Tahapan selanjutnya adalah memproses data yang dilakukan secara bertahap. Pertama, dilakukan penguraian unsur Kanji yaitu Kanji simbol perempuan sebagai unsur pertama (bushu) dan unsur ke dua sebagai penentu makna. Tahap kedua, mengidentifikasi makna leksikal dari unsur kedua sebagai Kanji bagian (part). Tahap ketiga mengidentifikasi makna denotatif dari tiap-tiap Kanji gabungan data sebagai keseluruhan (whole). Tahap keempat mengidentifikasi makna konotatif. Makna konotatif disebut pula makna asosiasi karena makna ini merupakan hubungan antara makna asli dengan makna baru di dalam lingkungan tempat kata itu dipindahkan ke dalam pemakaian bahasa (Pateda, 2010). Makna ini dapat diasosiasikan dengan waktu, peristiwa, tempat, warna, bunyi, lambang-lambang tertentu, dan lain-lain berdasarkan konvensi masyarakat yang ada di lingkungan tersebut. Indentifikasi makna konotatif dalam kajian ini dilakukan dengan cara mengasosiasi data dengan lambang, yaitu unsur kedua dari Kanji ber-bushu onna atau onnahen berdasarkan pada analisis semiotika sebagai ancangan dalam metode interpretatif.

Dalam menginterpretasi data digunakan teori relasi bushu atau metonimi dari unsur-unsur pembentuk Kanji onnahen (Danasubrata, 2011, pp. 5-10). Hasil dari proses ini, teridentifikasi makna konotatif atau asosiatif dari tiap-tiap data. Setelah teridentifikasi makna konotatif atau asosiatif dilanjutkan pada identifikasi tingkat makna dengan teridentifikasinya makna yang berkaitan dengan 
semantik budaya (cultural semantics). Selanjutnya, dilakukan identifikasi fungsi, peran, dan karakter sebagai representasi perempuan Jepang. Tahap terakhir adalah penarikan simpulan.

\section{Hasil dan Pembahasan}

Dalam bagian ini dideskripsikan tujuh data berupa Kanji yang berleher (ber-bushu) dengan simbol perempuan (女). Hubungan antara Kanji (unsur ke satu) dan Kanji (unsur kedua) ini dianggap sebagai tanda. Dengan demikian diidentifikasi hubungan antarkanji atau antartanda tersebut. Hubungan antartanda tersebut dilandasi oleh teori metonimi. Metonimi adalah interaksi tanda yang diasosiasikan dengan tanda lain, berdasarkan hubungan bagian (part) dengan keseluruhan (whole) (Piliang, 2003, p. 263). Interaksi tanda yang dimaksud dalam Kanji ber-bushu simbol perempuan ini yaitu Kanji penggabung sebagai unsur kedua yang melekat pada Kanji ber-bushu onnahen. Struktur dan makna Kanji tersebut dapat dilihat dalam Tabel 1.

Tabel 1: Struktur dan Makna Kanji Ber-bushu Onnahen

\begin{tabular}{|c|c|c|c|c|c|}
\hline \multirow[t]{2}{*}{ No } & \multirow[t]{2}{*}{ Kanji Onnahen } & \multicolumn{2}{|c|}{ Terdiri Atas } & \multirow[t]{2}{*}{ Makna Denotatif } & \multirow[t]{2}{*}{ Makna Konotatif } \\
\hline & & Unsur 1 & Unsur 2 & & \\
\hline 1 & $\begin{array}{l}\text { 姓セイ (sel) } \\
\text { ショウ (shoo) }\end{array}$ & $\begin{array}{l}\text { 女 } \\
シ ゙ ョ \quad(\text { jo }) \\
\text { ニョ (nyo) } \\
\text { ニ } \quad(\text { nyoo }) \\
\text { (Perempuan) }\end{array}$ & $\begin{array}{l}\text { 生 } \\
\text { Onyomi } \\
\text { セイ (seI) } \\
\text { ショウ (shoo) } \\
\text { (lalui; hidup; } \\
\text { mentah; } \\
\text { berkembang) } \\
\text { Kunyomi } \\
\text { いかす } \\
\text { いきる } \\
\text { いける } \\
\text { うまれる } \\
\text { うむ } \\
\text { はえる } \\
\text { はやす } \\
\text { なま } \\
\text { (menghidupkan; } \\
\text { hidup; dilahirkan; } \\
\text { lahir; melahirkan, } \\
\text { tumbuh, } \\
\text { menumbuhkan, } \\
\text { mentah) }\end{array}$ & $\begin{array}{l}\text { nama keluarga; nama } \\
\text { baru yang dianugrahkan } \\
\text { oleh kaisar }\end{array}$ & $\begin{array}{l}\text { perempuan akan menjadi } \\
\text { terhormat dengan penambahan } \\
\text { nama (dari pihak keluarga laki- } \\
\text { laki). }\end{array}$ \\
\hline 2 & 姻イン (in) & $\begin{array}{l}\text { 女 } \\
シ ゙ ョ \quad(j o) \\
\text { ニョ }(\text { nyo }) \\
\text { ニョ } \quad(\text { nyoo }) \\
\text { (Perempuan) }\end{array}$ & $\begin{array}{l}\text { 因 } \\
\text { Onyomi } \\
\text { イン (in) } \\
\text { Kunyomi } \\
\text { よる } \\
\text { (Penyebab; faktor; } \\
\text { berhubungan } \\
\text { dengan) }\end{array}$ & perkawinan & $\begin{array}{l}\text { Perempuan sebagai paduan atau } \\
\text { tempat yang berhubungan dengan } \\
\text { jenis kelamin lain secara resmi. }\end{array}$ \\
\hline 3 & 妊 ニン (nin) & $\begin{array}{l}\text { 女 } \\
シ ゙ ョ \quad(\text { jo }) \\
=\exists \quad(\text { nyo }) \\
=\exists \quad \text { (nyoo) } \\
\text { (Perempuan) }\end{array}$ & $\begin{array}{l}\text { 任 } \\
\text { Onyomi } \\
\text { =ン (nin) } \\
\text { (tugas, tanggung } \\
\text { jawab, misi, } \\
\text { jabatan) }\end{array}$ & hamil & $\begin{array}{l}\text { Hanya perempuan yang bisa } \\
\text { hamil. Hal ini merupakan salah } \\
\text { satu tanggung jawab atau amanah } \\
\text { bagi seorang perempuan yang } \\
\text { tidak bisa diwakilkan pada laki- } \\
\text { laki. }\end{array}$ \\
\hline
\end{tabular}




\begin{tabular}{|c|c|c|c|c|c|}
\hline \multirow[t]{2}{*}{ No } & \multirow[t]{2}{*}{ Kanji Onnahen } & \multicolumn{2}{|c|}{ Terdiri Atas } & \multirow[t]{2}{*}{ Makna Denotatif } & \multirow[t]{2}{*}{ Makna Konotatif } \\
\hline & & Unsur 1 & Unsur 2 & & \\
\hline & & & $\begin{array}{l}\text { Kunyomi } \\
\text { まかす、まかせる } \\
\text { (menyerahkan) }\end{array}$ & & \\
\hline 4 & 婚 コン (kon) & $\begin{array}{l}\text { 女 } \\
シ ゙ ョ \quad(j o) \\
=\exists \quad(\text { nyo }) \\
=\exists \quad(\text { nyoo }) \\
\text { (Perempuan) }\end{array}$ & $\begin{array}{l}\text { 昏 } \\
\text { Onyomi } \\
\text { コン (kon) } \\
\text { (berasal dari } \\
\text { tasogareru, hari } \\
\text { menjelang senja) }\end{array}$ & perkawinan & $\begin{array}{l}\text { Perempuan setelah menikah } \\
\text { bermetamorfosis. Siap } \\
\text { meninggalkan dunia bebas untuk } \\
\text { memiliki anak dan menyiapkan } \\
\text { masa tua }\end{array}$ \\
\hline 5 & 好 コウ $(k o o)$ & $\begin{array}{l}\text { 女 } \\
シ ゙ ョ \quad(\text { jo }) \\
\text { ニョ (nyo) } \\
\text { ニ }(\text { nyoo }) \\
\text { (Perempuan) }\end{array}$ & $\begin{array}{l}\text { 子 } \\
\text { シ }(s h i) \\
\text { ス }(s u) \\
\text { (Anak) }\end{array}$ & $\begin{array}{l}\text { suka, gemar, cinta, } \\
\text { persahabatan, gaya, } \\
\text { mode, keintiman, } \\
\text { kemauan baik, tanpa } \\
\text { ragu }\end{array}$ & $\begin{array}{l}\text { perempuan memiliki sifat } \\
\text { penyayang seperti sayangnya ibu } \\
\text { terhadap anak. }\end{array}$ \\
\hline & 姉 シ (shi) & $\begin{array}{l}\text { 女 } \\
シ ゙ ョ \quad(j o) \\
=\exists \quad(\text { nyo }) \\
=\exists \quad(\text { nyoo }) \\
\text { (Perempuan) }\end{array}$ & $\begin{array}{l}\text { 市 } \\
\text { Onyomi } \\
\text { シ (shi) } \\
\text { (kota, pasar) }\end{array}$ & $\begin{array}{l}\text { kakak perempuan, } \\
\text { pelayan perempuan, } \\
\text { nona, nyonya }\end{array}$ & $\begin{array}{l}\text { perempuan dihargai dan dihormati } \\
\text { karena mendapat kepercayaan } \\
\text { untuk mengatur uang belanja dan } \\
\text { mengatur rumah tangga. }\end{array}$ \\
\hline 7 & 婦 フ $(f u)$ & $\begin{array}{l}\text { 女 } \\
シ ゙ ョ \quad(j o) \\
=\exists \quad(\text { nyo }) \\
=\exists \quad(\text { nyoo }) \\
\text { (Perempuan) }\end{array}$ & $\begin{array}{l}\text { 帚 } \\
\text { Onyomi } \\
\text { フ、ブ } \\
\text { はく (haku) } \\
\text { (Menyapu) }\end{array}$ & $\begin{array}{l}\text { keramahan isteri, } \\
\text { pengantin perempuan }\end{array}$ & $\begin{array}{l}\text { perempuan sebagai pengabdi dan } \\
\text { bertanggung jawab untuk } \\
\text { mengurus lingkungan rumah } \\
\text { tangga dan mengerjakan berbagai } \\
\text { kegiatan diantaranya } \\
\text { membereskan rumah secara } \\
\text { keseluruhan. }\end{array}$ \\
\hline
\end{tabular}

Pertama, Kanji 姓セイ (sei) atau ショウ (shoo) merupakan gabungan atau kombinasi dari dua unsur Kanji yaitu Kanji 女(onna) dan Kanji 生 yang memiliki onyomi セイ (sei) dan ショウ (shoo). Dalam Kanji berbushu onnahen Kanji penggabung atau Kanji unsur kedua merupakan tanda yang berfungsi untuk menyatakan makna dari Kanji tersebut. Kanji sebagai unsur kedua atau セイ (sei) dan ショウ (shoo) ini memiliki makna denotatif sebagai uji (氏). Menurut Shinmura dalam koujien (Kamus Besar Bahasa Jepang) uji adalah chien kankei no aru kazokumure de kousei sareta shuudan 'kelompok yang membentuk kumpulan keluarga yang memiliki hubungan darah' (Shinmura, 1991, p. 220). Dengan kata lain セイ (sei) dan ショウ (shoo) yang bermakna sebagai uji adalah nama keluarga. Jadi, Kanji 生 yang melekat pada Kanji onnahen berfungsi sebagai penanda yang menandai perempuan yang namanya telah dilekati dengan nama keluarga baru. Hal ini menandakan bahwa perempuan tersebut sudah dianggap sebagai keluarga yang terikat dengan hubungan darah. Dalam masyarakat Jepang, perempuan yang telah menikah nama keluarga asal akan diganti dengan nama keluarga dari suaminya.

Kedua, Kanji onnahen dalam Kanji 姻 dilekati oleh Kanji yang 因 yang memiliki cara baca onyomi イン (in). Secara etimologi Kanji 因 menggambarkan kasur atau futon (口) yang di atasnya terdapat huruf dai (大). Hal ini mengeksprersikan hitotsu no koto ga, tsugi ni okoru koto (Toudou, 1987:181) 'sesuatu hal selanjutnya akan menyebabkan terjadinya sesuatu'. Dan menurut kamus Cina -Jepang atau Kokugo Kanwa Jiten, Kanji 因 bermakna yomeiri 'menikah dan masuk pada keluarga suaminya' atau mukotori 'diambil keluarga suami' (Horiuchi, 1978, p. 714). Kanji 因 sebagai unsur kedua dari 
姻 berfungsi sebagai penanda yang menandai onnahen, atau dengan kata lain, Kanji 因 menjadi simbol bahwa perempuan tersebut sudah masuk dan diakui sebagai keluarga suami melalui pernikahan. Berdasarkan kedua definisi tersebut, terdapat korelasi yang sangat erat antara Kanji onnnahen (女) dan Kanji 因, yang menandakan bahwa perempuan diakui sebagai keluarga lakilaki atau masuk pada keluarga laki-laki melalui pernikahan dan wajib menjadi penerus keluarga suami tersebut.

Ketiga, Kanji 妊 merupakan Kanji onnahen yang dilekati oleh Kanji 任 (nin, jin) baik berninben (イ) maupun tidak secara makna sama. Kanji 任 secara baca Jepang atau kunyomi dibaca haramu atau migomoru yang bermakna menyelimuti. Hubungan antara Kanji (女) dengan Kanji 任 sebagai petanda yang menunjukkan hubungan fungsional yaitu perempuan yang menyelimuti (janin atau mengandung janin) atau hamil.

Keempat Kanji 婚 (kon). Kanji ini merupakan kombinasi Kanji onnahen (女) dengan Kanji 昏(kon). Dalam kamus Cina-Jepang (Kanwa Jiten) Kanji 昏(kon) bermakna yomeiri (Horiuchi, 1978, p. 790). Kata yomeiri dalam bahasa Indonesia sepadan dengan kata pernikahan. Jadi, Kanji 昏(kon) berfungsi sebagai petanda yang menandai Kanji onnahen yang mengekspresikan perempuan yang sudah menikah. Dengan kata lain, hubungan antara unsur pertama dan kedua menyatakan status.

Kelima Kanji 好 (koo). Kanji ini memiliki cara baca Cina atau onyomi シ (shi) dan ス (su) dan cara Jepang atau kunyomi yaitu konomu 'suka', suku 'menyukai atau menggemari', dan yoshimi 'persahabatan'. Kanji 好(koo) merupakan Kanji kombinasi antara bushu onnahen (女) dan Kanji 子 (ko)'anak'. Kanji 好 (koo) bermakna suki 'suka', nakayoshi 'akrab'. Hubungan antara Kanji 女 'perempuan' dan 子'anak' berdasarkan makna denotif tiap-tiap unsur menunjukkan makna "terhadap", yaitu perempuan menyukai anak atau akrab dengan anak-anak.

Keenam, Kanji 姉 (shi). Merupakan Kanji gabungan antara onnahen (女) dengan Kanji 市 (shi) atau ichi. Kanji 市 secara etimologis menggambarkan pohon yang tumbuh menjulang. Secara makna mengekspresikan tempat berkumpulnya orang-orang dan menjadi pintu masuknya pajak (Toudoiu, 1987, p. 278). Definisi ini diperkuat oleh Shinmura yang menyebutkan bahwa Kanji 市 adalah shinamono no koukan ya baibai o okonau tokoro 'tempat jual beli dan tukar-menukar barang' (Shinmura, 1991, p. 145). Hubungan antara Kanji onnahen sebagai unsur pertama dan Kanji unsur kedua ini menyatakan fungsi atau tugas. Dalam masyarakat Jepang perempuan yang bertugas berbelanja ke pasar adalah kakak perempuan (ane 姉).

Ketujuh Kanji 婦 ( $f u$ ) atau bu. Kanji ini merupakan gabungan antara bushu onnahen (女) dengan Kanji haku (掃 $<$ ) tanpa tehen. Secara etimologis Kanji ini mengekspresikan perempuan yang memegang sapu (houki o motta onna o arawasu) yang bertugas membersihkan altar. Selain itu, disebutkan pula Kanji ini pun mengekspresikan seorang istri yang mengikuti suami (Yoshida, 1971, p. 350).

Berdasarkan makna konotatif dari Kanji ber-bushu onnahen, teridentifikasi bahwa perempuan Jepang akan dihargai oleh masyarakat apabila menikah, berganti nama keluarga, memiliki 
keturunan dan mampu mengurus rumah tangga atau mengerjakan pekerjaan domestik dengan baik. Latar belakang peran dan kedudukan perempuan Jepang ini tidak terlepas dari faktor historis perempuan Jepang dalam masyarakatnya.

Menurut naskah-naskah Cina, bahwa di Jepang dalam abad ke-3 terdapat banyak perempuan yang memegang kepemimpinan negara (Hartono, 2007). Hal ini sesuai dengan mitologi bangsa Jepang, yang menceriterakan asal usul garis kekaisaran berasal dari Dewi Matahari (Amaterasu Omikami). Pandangan tersebut diperkuat oleh Ishii bahwa sekitar tahun 200-an Jepang dipimpin oleh seorang ratu bernama Ratu Himiko yang sudah menganut Tenosentris (Sunarni, 2008). Bahkan pada zaman Heian sekitar tahun 794 tidak sedikit kaum perempuan yang menjadi sastrawan. Namun, memasuki zaman Kamakura, Jepang membuat lapisan masyarakat yang disebut lapisan shi, no, ko, shou. Shi kependekan dari bushi 'kaum bushi' sebagai kaum yng memiliki derajat paling tinggi. Kaum kedua yaitu no asal kata nouka 'petani'; lapisan ketiga yaitu ko asal kata kougyou 'kaum pertukangan', dan sho asal kata shoubai 'pedagang' (Ouguchi, 1991). Selama masa feodal kedudukan kaisar hanya sebagai pemimpin tertinggi agama dan lambang persatuan bangsa, kekuasaan dalam politik diambil alih oleh Shogun dan tahta kekaisaran Jepang didominasi oleh kaum pria.

Sistem politik isolasi (sakoku) masa Shogun Tokugawa turut berpengaruh pada kedudukan dan peranan perempuan. Pembatasan kekuasaan kaisar itu sekaligus memperkecil peranan kaum perempuan, karena kekuasaan golongan samurai semakin besar. Posisi kaum perempuan dalam hierarki sosial sangat rendah, peranan perempuan hanyalah mengabdi kepada kaum pria. Kaum perempuan dididik agar taat setia kepada keluarga, terutama orang tua dan suami. Perempuan dari golongan bangsawan diajarkan tentang etika tradisional agar dapat melayani tamu dengan baik. Fungsi sosial kaum perempuan dihargai sebagai kaum ibu karena melahirkan anak dan membesarkan para pengganti kepala keluarga. Kedua peran perempuan yaitu sebagai pengabdi kepada suami dan sebagai ibu merupakan dua peran yang sangat fundamental. Peran-peran ini tercermin dalam Kanji ber-bushu onnahen 姓セイ (sei) atau ショウ(shoo), 姻 (in), 妊 (nin), 婚 (kon), 好 (koo), 姉 (shi), 婦 (fu).

Kanji 姓セイ (sei) atau ショウ (shoo) menunjukkan bahwa perempuan menjadi terhormat apabila sudah menikah sehingga namanya ditambah dengan nama keluarga dari pihak laki-laki. Hal ini maksudnya perempuan Jepang akan dihargai apabila menikah yang tercermin dalam Kanji 姻 (in) yang bermakna menikah. Sebagai istri perempuan Jepang harus taat pada suami walaupun para suami pulang ke rumah dalam keadaan mabuk namun tetap harus mengabdi. Tiga kata budaya lakilaki terhadap istrinya setelah pulang ke rumah yaitu furo 'mandi', gohan 'nasi', dan neru'tidur'. Furo yaitu bahasa laki-laki dan bahasa perempuan disebut ofuro (ragam halus). Kata ini maksudnya istri harus menyediakan keperluan mandinya suami setelah pulang kerja di malam hari. Gohan memiliki makna denotatif yaitu nasi. Maksud dari kata gohan ini adalah seorang istri harus menyediakan makan malam untuk suaminya, dan neru maksudnya seorang istri harus menciptakan suami bisa tidur dengan nyaman.

Dengan menikah otomatis tidak hanya perubahan nama keluarga yang berubah. Namun perempuan Jepang akan berubah menjadi seorang ibu yang mampu menambah panjang keturunan. Pernikahan di Jepang memiliki tiga fungsi. Pertama, dari sudut pandang rumah tangga pernikahan merupakan cara untuk menarik anggota baru dalam rumah tangga. Seorang pengantin perempuan diharapkan akan mengisi posisi sebagai shufu (nyonya rumah) dan pengantin laki-laki sebagai shujin 
(tuan rumah). Kedua dari sudut pandang struktur "pohon keluarga" pengantin perempuan dan pengantin laki-laki diperlukan bagi penerus garis keturunan. Kedudukan istri akan terancam apabila ia belum juga melahirkan seorang anak. Fungsi ketiga, adalah penyatuan dua keluarga dari kedua belah pihak. Pernikahan menyatukan dua ie untuk membentuk shinseki yang saling menguntungkan keduanya (Roosiani, 2016).

Hal ini menunjukkan bahwa keturunan bagi masyarakat Jepang sangat penting, dan hanya kaum perempuan yang mampu memberikan keturunan. Setelah memiliki keturunan perempuan Jepang siap untuk meninggalkan dunia kerja, meninggalkan kebebasannya di luar untuk mengabdi pada suami, mengurus, mendidik, dan membesarkan anak yang ditunjukkan oleh Kanji 婚 (kon). Peranperan perempuan Jepang ini seolah-olah hanya bertugas dalam kegiatan domestik keluarga. Namun, dibalik peran tersebut terdapat kekuatan yang mampu memberikan kontribusi terhadap kemajuan bangsa.

Peran perempuan Jepang selain disimbolkan dengan Kanji dapat ditemukan pula dalam peribahasa yaitu onna wa kuni no taira 'perempuan menjadi dasar kekuatan negara' (Sunarni \& Johana, 2017). Peribahasa tersebut sepadan juga dengan peribahasa Indonesia yang berbunyi "Perempuan sebagai tiang negara." Dasar yang dimaksud dalam peribahasa Jepang di atas merujuk pada sebuah fondasi. Karena rumah orang Jepang memiliki fondasi sedangkan rumah tradisional atau rumah panggung di Indonesia ditentukan dengan tiang-tiang sebagai penyangga rumah. Jadi, baik fondasi maupun tiang keduanya sama sebagai penyangga sebuah rumah. Rumah dalam hal ini merujuk pada penyangga sebuah negara. Apa yang menjadi penyangganya yaitu kaum perempuan sebagai ibu. Dari peribahasa tersebut dapat diketahui bahwa perempuan menjadi dasar atau fondasi bagi kekuatan keluarga, masyarakat, dan negara.

Peran perempuan Jepang dalam fungsinya sebagai pelaksana kegiatan domestik, dapat dikatakan pula bahwa perempuan Jepang dianggap sebagai "dompet keluarga", dalam bahasa Inggrisnya disebut juga sebagai household economy (AOTS, 1987). Yang dimaksud dengan ungkapan ini adalah bahwa kaum perempuan atau para istri di Jepang berperan sebagai pemegang keuangan keluarga. Hal ini diwujudkan dalam Kanji 姉 (shi). Di balik Kanji ini terdapat makna bahwa perempuan Jepang dihargai dan dihormati karena mendapat kepercayaan untuk mengatur uang belanja dan mengatur roda perekonomian dalam rumah tangga. Kaum laki-laki menyerahkan keuangannya atau penghasilannya kepada istrinya. Bahkan, hal ini ditemukan pula dalam kalimat "Boku wa kyuuryou o zenbu kanai ni watashi, sono naka kara 4 man en kozukai to shite moraimasu" (AOTS, 1987). Bila diterjemahkan kalimat tersebut 'gaji saya semuanya diserahkan kepada istriku. Saya hanya menerima uang saku empat puluh ribu yen dari jumlah gaji'. Karena semua keuangan diatur oleh istri jadi istri harus benar-benar mampu mengatur keuangan rumah tangga dengan baik.

Para ibu rumah tangga di Jepang memiliki tanggung jawab penuh dalam mengurus keuangan rumah tangga. Hal ini disebabkan uang gaji suami masuk pada rekening tabungan keluarga. Keputusan urusan domestik ada di pihak istri (Rosidi, 2003). Selain peran sebagai pelaksana pengatur perekonomian keluarga, perempuan Jepang pun otomatis harus mengurus rumah dengan bersih, rapi, indah, dan nyaman bagi semua penghuninya. Di Jepang hanya masyarakat tertentu yang memiliki asisten rumah tangga. Pada umumnya semua pekerjaan rumah dikerjakan oleh sang istri. Oleh karena itu, perempuan Jepang harus terampil dalam menata rumah. Keindahan rumah orang Jepang ditentukan oleh keterampilan dan rasa perempuan Jepang. Perempuan Jepang wajib menjadi sosok manusia yang indah, bersih, rapi, berbudi pekerti halus dan penyayang. Hal ini 
tercermin dalam Kanji 好(koo). Kanji ini disebut penyayang sesuai dengan pendapat Toudou Akiyasu yang menyebutkan bahwa Kanji 好(koo) merupakan Kanji gabungan yang merepresentasikan sayangnya ibu terhadap anak (Akiyasu, 1992). Hal ini terkait dengan fungsinya di dalam keluarga yang harus membereskan rumah sebagai ruang pertemuan keluarga. Filosofis masyarakat Jepang disebutkan membereskan ruangan atau tempat tinggal dapat membantu membereskan pikiran (Kempton, 2018). Peran ini tercermin dalam Kanji 婦 ( $f u$ ). Berdasarkan analisis data dalam kajian ini teridentifikasi bahwa ketujuh Kanji tersebut di atas memiliki makna budaya (cultural semantics) yang mencerminkan bahwa perempuan Jepang sebagai istri berperan sebagai fungsi pelaksana kegiatan domestik dalam keluarganya. Seiring dengan munculnya Western Shock dan munculnya kesadaran 'Budaya Jepang yang Terbelakang' pada bulan April tahun 1868, pemerintah baru atas nama kaisar mengumumkan kebijakan di antaranya yaitu "semua lapisan masyarakat harus kompak dalam memajukan ekonomi negara dan proaktif menimba ilmu ke mancanegara, agar Jepang berjaya" (ONG, 2019, p. 88). Sejak adanya kebijakan tersebut Jepang mulai membuka membebaskan masyarakatnya untuk menuntut ilmu lebih tinggi. Hal ini dapat dibuktikan dengan berdirinya lembaga-lembaga pendidikan untuk kaum perempuan. Sejak itu, kaum perempuan tidak hanya bertugas dalam urusan domestik saja, namun sudah banyak yang berkiprah di dunia pendidikan dan dunia profesional lainnya. Bahkan pada tahun 1994 terdapat astronot perempuan Jepang pertama yang bernama Chiaki Mukai.

\section{Simpulan}

Kanji ber-bushu onnahen yang menggambarkan perempuan Jepang, menunjukkan perannya sebagai istri yang memiliki kecerdasan dalam mengatur rumah tangga, pengabdi terhadap suami, pembentuk keberhasilan anak, dan pengatur rumah tangga sehingga seluruh anggota keluarga merasakan kenyamanan dan kesejahteraan. Anggapan bahwa perempuan Jepang direndahkan oleh kaum laki-laki sebagai masyarakat kelas dua dapat dipatahkan dengan perannya sebagai sosok manusia yang memiliki kekuatan dan berkontribusi terhadap negara melalui keberhasilan anaknya sebagai aparatur negara. Berdasarkan peran-peran perempuan di atas teridentifikasi bahwa perempuan Jepang memiliki karakter pengabdi, penyayang, pejuang, dan ekonomis.

\section{Referensi}

Akiyasu, T. (1992). 漢語と日本語. 秀英出版.

AOTS. (1987). Japanese Life Today. AOTS Chosakai, Ltd.

Berger, A. A. (2010). Pengantar Semiotika: Tanda-tanda dalam Kebudayaan Kotemporer. Tiara Wacana.

Danasubrata, A. (2011). Bushu. Sastra Unpad Press.

Endo, Y. et. al. (1986). Nippongo 7 Kanji. Mugi Shobo.

Hartono, M. (2007). Wanita Jepang Dalam Perspektif Historis. MOZAIK, 2(1).

Hoed, H. B. (2011). Semiotik dan Dinamika Sosial Budaya. Komunitas Bambu. 
Horiuchi, M. (1978). 国語漢和辞典. Shueisha.

Kempton, B. (2018). Wabi Sabi: seni menemukan keindahan dalam ketidaksempurnaan. PT Gramedia Pustaka Utama.

Kess, J. F., \& Miyamoto, T. (1999). The Japanese Mental Lexicon: Psycholinguistic Studies of Kana and Kanji processing. John Benjamins Publishing Company.

Khoiriyah, A. R. (2014). Mengenal Lebih Dekat Mengenai Bushu Kanji. DIGLOSSIA, 5(2), 78-93.

ONG, S. (2019). Seikatsu Kaizen: Reformasi Pola Hidup Jepang. PT Elex Media Komputindo.

Ouguchi, Y. et. a. (1991). 留学生のための日本史. Yamakawa Shuppan.

Pateda, M. (2010). Semantik Leksikal. PT Rineka Cipta.

Piliang, Y. (2003). Hipersemiotika (Tafsir Cultural Studies Atas Matinya Makna). Jalasutra.

Roosiani, I. (2016). Kedudukan Perempuan Dalam Masyarakat Jepang. WAHANA, 1(13), 70-79.

Rosidi, A. (2003). Orang dan Bambu Jepang: Catatan Seorang Gaijin. Pustaka Jaya.

Shinmura, I. (1991). 広辞苑. Iwanami Shoten.

Sunarni, N. (2008). Tindak Tutur Penolakan Dalam Bahasa Jepang (Suatu Kajian Pragmatik). Universitas Negeri Surabaya.

Sunarni, N., \& Johana, J. (2017). Citra Perempuan dan Pria dalam Budaya Jepang. Balatin Pratama.

Toudoiu, A. (1987). 学習漢字辞典. Shougakukan.

Yoshida, Y. (1969). The First Step to Kanji. Osaka University of Foreign Studies.

Yoshida, Y. (1971). The Second Step to Kanji. Osaka University of Foreign Studies.

Yoshikazu, M. (1991). 日本人の考方方「日本論」への案内. The Japan Foundation Japanese Language Institute. 